\title{
Mateusz Ułanowicz
}

Uniwersytet w Białymstoku e-mail: ulanowicz96@gmail.com

ORCID: 0000-0002-5970-9378

DOI: 10.15290/mhi.2021.20.01.08

\section{Karol Brzostowski i jego Instytucja Rolno-Fabryczna Sztabińska}

\begin{abstract}
ABSTRAKT
Karol Brzostowski urodził się w 1796 r. Jego rodzicami byli Ewa z Chreptowiczów i Michał Hieronim. Dziadkiem Karola był Joachim Litawor Chreptowicz - pisarz, poeta, działacz Komisji Edukacji Narodowej. Karol Brzostowski był znanym w I połowie XIX w. właścicielem ziemskim. Gospodarzył w dobrach sztabińskich. Jego największym osiągnięciem w dziedzinie rozwoju przemysłu było założenie osady Huta Sztabińska, w której znajdowały się: fabryka maszyn i narzędzi rolniczych; huta szkła, odlewnia oraz wielki piec. W swoim testamencie, napisanym 29 listopada 1853 r., nadał sztabińskim włościanom ziemię na własność, a z reszty majątku utworzył Fundusz Fabryk, zwany Instytucją Rolną-Fabryczną Sztabińską. Instytucja zaczęła funkcjonować 1 stycznia 1855 r., kilka miesięcy po śmierci testatora. Jej majątek składał się z zakładów przemysłowych oraz posiadłości rolnych. W 1948 r. pozostałości Instytucji, w postaci lasu zwanego Parcelacją Sztabińską, stały się własnością państwa. Podstawowym celem artykułu jest przedstawienie krótkiego zarysu dziejów Instytucji Rolno-Fabrycznej Sztabińskiej. Najważniejszym źródłem, dającym podstawę do jej istnienia, jest wspomniany testament Karola Brzostowskiego. O Instytucji RolnoFabrycznej Sztabińskiej pisali m.in. L. Pietrusiński, J. Rółkowski, I. W. Kosmowska, J. Bartyś, G. Ryżewski, H. Zawistowska-Zacharewicz i S. Maciejewski. Akta, dotyczące Instytucji Rolno-Fabrycznej Sztabińskiej, znajdują się m.in. w Archiwum Państwowym w Suwałkach oraz w Archiwum Głównym Akt Dawnych w Warszawie.
\end{abstract}




\begin{abstract}
Karol Brzostowski and His Sztabińska Agricultural and Factory Institution

Karol Brzostowski was born in 1796. His parents were Ewa Chreptowicz and Michał Hieronim. His grandfather was Joachim Litawor Chreptowicz - writer, poet, and activist of the Commision of National Education. Karol Brzostowski was a famous landowner in the first half of the 19th century. He was a farmer of the Sztabin estates. His greatest achievement in the field of industrial development was the establishment of the Sztabińska Huta settlement, in which there were: a factory of agricultural machines and tools; glassworks, foundry and a blast furnace. Karol Brzostowski was also an inventor and constructor. In his will, written on November 29, 1853, he granted Sztabin's provincial landowners ownership of the land, and from the rest of the property he created the Factories Fund, called the Sztabińska Agricultural and Factory Institution. The Institution started operating on January 1, 1855, a few months after the testator's death. Its property consisted of industrial plants and agricultural estates. A few years after his death, the Institution started to go bankrupt. In 1948, the remains of the Institution, in the form of a forest known as the Sztabin Parcellation, became property of the state. The main aim of this article is to present a short outline of the history of the Sztabińska Agricultural and Factory Institution. The most important source giving rise to its existence is the mentioned will of Karol Brzostowski. The Sztabińska Agricultural and Factory Institution was written about by, inter alia, L. Pietrusiński, J. Rółkowski, I.W. Kosmowska, J. Bartyś, G. Ryżewski, H. Zawistowska-Zacharewicz and S. Maciejewski. The files concerning the Sztabińska Agricultural and Factory Institution are located, among others, in the State Archives in Suwałki and the Central Archives of Historical Records in Warsaw.
\end{abstract}

Słowa kluczowe: Karol Brzostowski, testament, Sztabin, Instytucja Rolno-

-Fabryczna Sztabińska, prawo własności ziemi, Parcelacja Sztabińska

Key words: Karol Brzostowski, will, Sztabin, Sztabińska Agricultural and Factory Institution, land ownership, Sztabin Parcellation 
Celem artykułu jest przedstawienie zarysu dziejów Instytucji Rolno-Fabrycznej Sztabińskiej, która powstała na mocy testamentu hrabiego Karola Brzostowskiego, zmarłego 25 lipca 1854 r. ${ }^{1}$ Aby to uczynić, należy zapoznać się z sylwetką testatora, w szczególności z dyspozycjami, których dokonał na wypadek swojej śmierci.

Karol Brzostowski urodził się 11 lutego 1796 r. w Michaliszkach na Wileńszczyźnie. Jego rodzicami byli Michał Hieronim Brzostowski i Ewa z Chreptowiczów. Dziadkiem Karola był Joachim Litawor Chreptowicz (1729-1812) - kanclerz wielki litewski; inicjator i współzałożyciel Komisji Edukacji Narodowej oraz Towarzystwa Przyjaciół Nauk ${ }^{2}$. W wieku dwudziestu czterech lat Brzostowski zamieszkał na stałe w dobrach sztabińskich. Jego rezydencją został dwór w Cisowie. Ziemia sztabińska na mocy postanowienia namiestnika Królestwa Kongresowego generała Józefa Zajączka z 16 stycznia 1816 r. stała się częścią województwa augustowskiego ${ }^{3}$. Było to jedno z ośmiu województw, tworzących Królestwo Polskie. 23 lutego 1837 r. car Mikołaj I wydał postanowienie, zmieniające nazwę województwo na gubernia ${ }^{4}$. Symbolizowało to represje, jakie spadły na Polaków po przegranym powstaniu listopadowym. Głównym miastem guberni augustowskiej były Suwałki. Gubernia dzieliła się na pięć powiatów: łomżyński, sejneński, kalwaryjski, mariampolski oraz augustowski, w którym gospodarzył hrabia Karol Brzostowski ${ }^{5}$. 31 grudnia 1866 r. zlikwidowano gubernię augustowską, a powiat augustowski stał się częścią nowo utworzonej guberni suwalskiej ${ }^{6}$.

Odziedziczony przez hrabiego majątek znajdował się w bardzo trudnej sytuacji ekonomicznej. Okazją do poprawy sytuacji finansowej była budowa Kanału Augustowskiego. W miejscowości Janówek w drewnianym budynku po browarze, przy pomocy pochodzącego z Prus Wschodnich majstra o nazwisku Gize, Brzostowski wytapiał całymi dniami i nocami śluzy kanałowe, w międzyczasie studiując książki metalurgiczne ${ }^{7}$. Wyroby hrabiego cechowały się wysoką jakością ${ }^{8}$.

1 Testament Karola Hr. Brzostowskiego - wypis urzędowy, drukarnia Aleksandra Ginsa, Warszawa 1862.

2 S. Maciejewski, Szlachetni pasjonaci, Olsztyn 1978, s. 185.

3 Postanowienie Namiestnika Królestwa Polskiego z dnia 16 stycznia 1816 r., Dziennik Praw Królestwa Polskiego, t. 1, nr 1-7, s. 115-120.

4 Postanowienie Cesarza Wszech Rosji, Króla Polskiego z dnia 23 lutego 1837 r., „Dziennik Praw Królestwa Polskiego", t. 20, nr 68-70, s. 413-417.

5 A. Połujański, Opisanie lasów Królestwa Polskiego i Guberni Zachodnich Cesarstwa Rosyjskiego pod względem historycznym, statystycznym i gospodarczym, t. 1, Warszawa 1854, s. 333-334.

6 G. Ryżewski, Dzieje obszarów gminy Sztabin od czasów najdawniejszych do współczesności, Białystok-Sztabin 2002, s. 183.

7 L. Pietrusiński, Krasnybór czyli Sztabin i Karol Hr. Brzostowski, Warszawa 1863 r., Sztabin 1991, s. $27-28$.

8 A. Połujański, op. cit., s. 352. 
Największym osiągnięciem Karola Brzostowskiego w dziedzinie rozwoju przemysłu było założenie osady Huta Sztabińska. W osadzie znajdowała się huta szkła, produkująca m.in.: szklane naczynia stołowe, laboratoryjne, aptekarskie oraz butelki ${ }^{9}$. W 1825 r. zaczęła funkcjonować odlewnia oraz wielki piec. Miechy wielkiego pieca były uruchamiane za pomocą silnika parowego, który został skonstruowany przez hrabiego ${ }^{10}$. Za pomocą wielkiego pieca odlewano m.in.: kociołki i garnki żelazne, kotły, sagany, rondle, tygle, łyżki, widelce, moździerze, lichtarze, a nawet pomniki i nagrobki. Dzięki zaangażowaniu majstra Marcina Franke powstała w Hucie Sztabińskiej fabryka maszyn i narzędzi rolniczych, w której produkowano m.in.: młockarnie, młynki ręczne, sieczkarnie, szatkownice, pługi, latarnie uliczne itp. ${ }^{11}$ Obok dworu w Cisowie funkcjonował browar z gorzelnią. Browar słynął z wyśmienitego porteru, natomiast gorzelnia z wódki cukrowej ${ }^{12}$.

Oprócz niebywałego talentu organizatorskiego, Karol Brzostowski był również wynalazcą i konstruktorem. Zaprojektował oraz produkował w swoich fabrykach: maszynę do kopania ziemniaków, mechaniczną dojarkę, maszynkę do bicia masła, maszynę do obierania ziemniaków, urządzenie do mieszania ciasta chlebowego ${ }^{13}$. Ewenementem było funkcjonowanie linii telegraficznej, która łączyła dwór cisowski z Hutą Sztabińską ${ }^{14}$. Była to pierwsza linia elektromagnetyczna, uruchomiona w Królestwie Polskim.

Ciągła praca oraz troska o byt okolicznej ludności spowodowały u Brzostowskiego problemy z sercem. Będąc kawalerem i nie posiadając potomstwa, 18 grudnia 1853 r. hrabia ustanowił pełnomocnictwo do zarządu dóbr swojemu bliskiemu współpracownikowi Marcinowi Sztukowskiemu i wyjechał na leczenie do Królewca, a następnie do Paryża. Na obczyźnie Karol Brzostowski utrzymywał stałą korespondencję z zarządcą i troszczył się o swoje włości, jednak zmarł w stolicy Francji 25 lipca 1854 r. Pochowano go na cmentarzu Montmartre, później zaś zwłoki przewieziono na cmentarz Montmorency, gdzie znajdują się do dzisiaj ${ }^{15}$.

Wiadomość o śmierci hrabiego dotarła do Cisowa z miesięcznym opóźnieniem. Do dworu zjechał sąd pokoju z Suwałk. Odpieczętowano dokumenty, złożone w żelaznej skrzyni. Znajdował się w niej testament, napisany 29 listopada $1853 \mathrm{rr}^{16}$

9 J. Bartyś, Czerwony Hrabia Karol Brzostowski, Warszawa 1978, s. 195.

10 L. Pietrusiński, op. cit., s. 41.

11 Ibidem, s. 34.

12 J. Bartyś, op. cit., s. 236, 241.

13 Ibidem, s. 167-168.

14 Ibidem, s. 251.

15 L. Pietrusiński, op. cit., s. 18, 76-80.

16 Ibidem, s. 80. 
Testament Karola Brzostowskiego wszedł w życie 1 stycznia 1855 r. ${ }^{17}$ Testator objawił się w nim jako wielki reformator i społecznik, mający świadomość tego, co udało mu się osiągnąć przez lata swojej pracy ${ }^{18}$. Hrabia przedstawił siebie jako opiekuna sztabińskich włościan. Na kartach testamentu napisał: „Przez lat góra trzydzieści mojego zarządu w dobrach Sztabin doznałem przychylności włościan miejscowych, opiekowałem się też nimi, prowadziłem ich jako Ojciec [...] Włościanie, fabrykanci, oficjaliści i pomocnicy moi, oto są moje dzieci”19. Testament został wydany drukiem w 1855 r. przez drukarnię Józefa Ungera w Warszawie ${ }^{20}$. W 1862 r. uczyniła to również drukarnia Aleksandra Ginsa, publikując także testament podróżny ${ }^{21}$. Upublicznienie przez druk ostatniej woli hrabiego odbyło się za jego przyzwoleniem, które zawarł w testamencie. Brzostowski oświadczył, że chce, aby treść tego dokumentu dotarła do wszystkich zainteresowanych ${ }^{22}$.

$\mathrm{Na}$ początku testamentu hrabia potwierdził swoje prawo własności do majątku, którym dysponował. Stwierdził, że 15 czerwca 1836 r. nabył udział we współwłasności dóbr sztabińskich od swojej siostry Izabeli w zamian za roczną pensję, którą sumiennie wypłacał. W ten sposób stał się jedynym właścicielem dóbr sztabińskich. Bardzo ciekawym zagadnieniem jest również wzmianka w testamencie, zgodnie z którą dobra sztabińskie zostały wystawione na licytację z powodu zadłużenia i nabył je za moja prośba [Karola Brzostowskiego - przyp. M.U.] Antoni Kruszewski, który następnie odsprzedał je Brzostowskiemu 14 listopada 1849 r. pod warunkiem zapłacenia mu należnych stu tysięcy złotych ${ }^{23}$. W ten sposób Karol Brzostowski chciał uniknąć problemów z wierzycielem, którym było Towarzystwo Kredytowe Ziemskie. Pomógł mu w tym Antoni Kruszewski ${ }^{24}$.

Dysponując swoim majątkiem, Brzostowski przyznał w testamencie swojej siostrze Izabeli pensję roczną w wysokości dziesięciu tysięcy rubli ${ }^{25}$. Chciał w ten sposób zaspokoić ewentualne roszczenia siostry po jego śmierci. Nadzieje testatora okazały się płonne, o czym napiszę w dalszej części tekstu.

Fenomen testamentu Brzostowskiego polegał m.in. na tym, że stanowił on o uwłaszczeniu włościan dóbr sztabińskich. Kwestia nadania chłopom ziemi na

17 Testament Karola Hr. Brzostowskiego - wypis urzędowy, s. 8.

18 S. Maciejewski, op. cit., s. 211.

19 Testament Karola Hr. Brzostowskiego - wypis urzędowy, s. 1.

20 Wypis urzędowy testamentu ś. p. Karola Hr. Brzostowskiego, drukarnia Józefa Ungera, Warszawa 1855.

21 Testament Karola Hr. Brzostowskiego - wypis urzędowy.

22 Ibidem, s. 8.

23 Ibidem, s. 1.

24 Wywód apelacyjny Prokuratoryi w Królestwie Polskiem na rzecz gminy dóbr Sztabin i Krasnybór, czyli Instytucyi rolniczo-fabrycznej czyniącej przeciwko Izabelli hrabiance Brzostowskiej o ważności Testamentu śp. Karola hr. Brzostowskiego, Warszawa 1857, s. 51.

25 Testament Karola Hr. Brzostowskiego - wypis urzędowy, s. 1. 
własność była poruszana w trakcie obrad Towarzystwa Rolniczego - organizacji ziemiańskiej, istniejącej w latach 1858-1861; kierowanej przez Andrzeja Zamoyskiego ${ }^{26}$. Jej celem było dbanie o podnoszenie poziomu rolnictwa za pomocą nowoczesnych metod gospodarowania. 25 lutego $1861 \mathrm{r}$. Towarzystwo Rolnicze podjęło uchwałę, w której „objawia życzenie [Towarzystwo Rolnicze - przyp. M.U.], aby przez właściwą operacyę kredytową, skup czynszów na celu mającą, włościanie dopuszczeni zostali do własności posiadanych gruntów" ${ }^{27}$. Należy podkreślić, że wspomniana uchwała została podjęta prawie osiem lat po śmierci Brzostowskiego i poprzedzała ją burzliwa dyskusja. Nie wszyscy członkowie Towarzystwa byli zwolennikami idei uwłaszczenia chłopów. Potwierdza to jedynie, jakim wybitnym działaczem społecznym był Karol Brzostowski. Uwłaszczenie chłopów w Królestwie Polskim obwieścił Tymczasowy Rząd Narodowy w manifeście, wydanym 22 stycznia $1863 \mathrm{r}^{28}$ Miało to zachęcić włościan do wzięcia udziału w powstaniu styczniowym. Były to jednak „puste słowa”, ponieważ powstańcy nie sprawowali faktycznej władzy w Kongresówce. Na obszarze Królestwa Polskiego ukaz, uwłaszczający chłopów, został wydany przez cara Aleksandra II 19 lutego $1864 \mathrm{r}^{29}$ Monarcha uczynił to, ponieważ chciał zniechęcić chłopów do walki zbrojnej z Rosjanami, a nie polepszyć ich sytuację materialną. Car nie kierował się tak szlachetnymi pobudkami jak Karol Brzostowski.

Mieszkańcy dóbr sztabińskich zostali przez Brzostowskiego uwłaszczeni „bez względu na stan i religię" ${ }^{\text {”o }}$. Nadano im na własność ziemię, na której gospodarzyli w chwili śmierci testatora. Obszar gruntów objętych uwłaszczeniem wynosił około 240 włók, a nabywcami zostali mieszkańcy 26 wsi i osad ${ }^{31}$. Wydaje się, że myśl o uczynieniu chłopów sztabińskich właścicielami gruntów dojrzewała w głowie hrabiego przez długi czas, jednak Brzostowski chciał mieć pewność, że okoliczni włościanie są do tego przygotowani. Dlatego też w testamencie zaznaczył, że od chwili nabycia prawa własności to nowi właściciele są zobowiązani do płacenia danin na rzecz państwa ${ }^{32}$. Na początku swoich rządów hrabia wydzierżawiał chłopom ziemię w formie dzierżawy krótkoterminowej. Następnie sam pozwalał decydować dzierżawcy, na jaki czas umowa ma zostać zawarta. We dworze cisowskim znajdował się Dziennik Administracyjny. Ten dokument, określany też mianem Dziennika Dyspozycyjnego, zawierał wszyst-

26 W. Grabski, Historia Towarzystwa Rolniczego: 1858-1861 r., t. 2, Warszawa 1904.

27 Ibidem, s. 344.

28 Komitet Narodowy Komitet jako tymczasowy Rząd Narodowy [Inc.: Zważywszy, że uwłaszczenie włościan pomimo ogólnej chęci kraju, z powodu stawianych przez Rząd Najezdniczy przeszkód dotąd do skutku nie doszło - obok tego...], Warszawa 1863.

29 Ukaz o urzadzeniu Włościan, Dziennik Praw Królestwa Polskiego, t. 62, nr 187-193.

30 Testament Karola Hr. Brzostowskiego - wypis urzędowy, s. 2.

31 L. Pietrusiński, op. cit., s. 16.

32 Testament Karola Hr. Brzostowskiego - wypis urzędowy, s. 3. 
kie rozporządzenia Brzostowskiego, a także szczegółowe instrukcje, dyspozycje oraz przemyślenia ${ }^{33}$. Cechą szczególną Dziennika była nieustanna dostępność tego dokumentu do przeczytania w kancelarii dworskiej. Każdy mógł w nim napisać swoje spostrzeżenia, które hrabia brał pod uwagę ${ }^{34} .16$ czerwca $1852 \mathrm{r}$. Brzostowski napisał na kartach Dziennika Administracyjnego:

Kiedy początkowo rozdawałem grunty włościanom, nie miałem zamiaru ograniczać czasu ich posiadania i zaprowadzać tylko dzierżawy, zasada ta jednak nie mogła być od razu wprowadzona, gdyż wybuchły pomiędzy nimi targi i kłótnie, które zmusiły mnie do urządzenia licytacji przez co i cena morgów znacznie się podniosła. Teraz, gdy ten zwyczaj rozbierania morgów się ustalił, gdy się na nich dobrze zagospodarowano, uważam za stosowne nie ruszać nikogo z gospodarstwa i termin dzierżawy o ile można przedłużać. Biorący niech sam oznacza, dokąd chce trzymać ziemię ${ }^{35}$.

Rok później, pisząc testament, Brzostowski miał pewność, że mieszkańcom dóbr sztabińskich należy się prawo własności ziemi, na której od lat gospodarzyli.

Nabycie prawa własności przez chłopów zostało przez Brzostowskiego uzależnione od spełniania przez nich oraz „ich sukcesorów i prawnonabywców” następujących warunków ${ }^{36:}$

1. Przestrzeganie płodozmianu oraz dostarczanie na rzecz dworu części zebranych ziemniaków tzw. zsypka kartoflana;

2. Niepopełnianie czynów niedozwolonych. Brzostowski napisał: „Zastrzegam, iż każdy mieszkaniec dóbr tych, któryby dopuścił się krzywdy czyjejkolwiek, popełnił kradzież lub inny występek krzywdzący bliźniego, traci własność i wszelkie prawo przezemnie dziś nadane";

3. Unikanie pijaństwa. W treści testamentu czytamy: „Zastrzegam, iż każdy gospodarz domu, któryby w przeciągu jednego roku był trzy razy widziany $\mathrm{w}$ stanie opiłym lub nieprzytomnym $\mathrm{z}$ pijaństwa, ma zdać gospodarstwo żonie lub komu zechce przelać takowe, i za niezdolnego do utrzymania własnego gospodarstwa ma być uważanym";

4. Gospodarzenie na otrzymanej ziemi oraz mieszkanie w dobrach sztabińskich.

Brzostowski przyznał również chłopom prawo bezpłatnego zbierania suszu na opał oraz wypasania zwierząt na pastwiskach leśnych ${ }^{37}$.

Z reszty majątku utworzono Fundusz Fabryk, zwany też Instytucją Rolno-Fabryczną Sztabińską. Warto zadać sobie pytanie, dlaczego Brzostowski

33 J. Bartyś, op. cit., s. 9.

34 L. Pietrusiński, op. cit., s. 64.

35 I.W. Kosmowska, Karol Brzostowski, [w:] Mądrzy gospodarze, Warszawa 1917, s. 24.

36 Testament Karola Hr. Brzostowskiego - wypis urzędowy, s. 2.

37 Ibidem, s. 2. 
postanowił powołać do życia tę jednostkę organizacyjną? Odpowiedź została udzielona przez samego testatora, który napisał na kartach testamentu: „... pamiętać też winienem, że fabrykanci oraz dozorcy i oficjaliści, są też moje wychowanki; że i im winienem zostawić fundusz do życia" ${ }^{38}$. Z zacytowanego fragmentu wynika, że Brzostowskim kierowała przede wszystkim chęć zapewnienia miejsc pracy dla swoich wychowanków. Powierzchnia Instytucji wynosiła około 530 włók ${ }^{39}$. Majątek funduszu składał się z posiadłości rolnych i zakładów przemysłowych.

Na czele Instytucji Rolno-Fabrycznej Sztabińskiej stał administrator. Jego podstawowym zadaniem było kontynuowanie dzieła Brzostowskiego. Administrator miał obowiązek sprawować nadzór ojcowski nad mieszkańcami okolicznych wsi. Jego kompetencją było wyznaczenie swojego następcy, który musiał mieć skończone dwadzieścia pięć lat. W przypadku, gdyby nie zdążył tego uczynić, to wyższe władze rządowe miały wyznaczyć kolejnego administratora ${ }^{40}$.

Karol Brzostowski był człowiekiem bardzo pracowitym i zdyscyplinowanym. Tego samego wymagał od administratora Instytucji Rolno-Fabrycznej Sztabińskiej. W swoim testamencie określił wymogi, jakie powinien spełniać administrator ${ }^{41}$ :

1. Posiadanie wykształcenia technika i inżyniera oraz znajomość sposobu funkcjonowania fabryk, będących pod jego zarządem;

2. Stałe zamieszkiwanie $\mathrm{w}$ dobrach sztabińskich i osobiste prowadzenie zarządu. Bez wyraźnej przyczyny, administrator mógł wyjechać z Cisowa maksymalnie na miesiąc, a w sprawach koniecznych na trzy miesiące. Podczas jego nieobecności, obowiązki administratora miał spełniać wyznaczony zarządca, który otrzymywałby pensję, jaka przez ten czas należała się nieobecnemu;

3. Niezajmowanie się hazardem;

4. Dawanie przykładu innym oraz sprawowanie nadzoru nad włościanami;

5. Prowadzenie jawnej administracji, będącej pod kontrolą rachunkową;

Kompetencją administratora było mianowanie i usuwanie oficjalistów, fabrykantów i innych stużacych stałych. Jego prawo nie było jednak nieograniczone $^{42}$ :

1. Oficjalistą oraz fabrykantem nie mógł zostać krewny administratora oraz osoba z nim spowinowacona;

38 Ibidem, s. 3.

39 Ibidem.

40 Ibidem, s. 4.

41 Ibidem.

42 Ibidem, s. 5. 
2. Administrator nie mógł usunąć oficjalisty, który za życia Brzostowskiego był zasłużony. W dodatku do testamentu hrabia sporządził specjalną listę z nazwiskami takich osób;

3. Administrator nie mógł wydalić oficjalisty, który służył bez przerwy przez piętnaście lat;

4. W przypadku, gdyby niesforność, opuszczenie się lub inna wada zmuszałyby administratora to usunięcia osób, wspomnianych w pkt. 1-3, administrator był zobowiązany nadal wypłacać im emeryturę. Dla tych, którzy służyli co najmniej dwadzieścia lat, emerytura miała być wypłacana w całości, natomiast osoby, które służyły co najmniej lat piętnaście, miały otrzymywać połowę świadczenia.

Testament Brzostowskiego zawierał dalsze postanowienia, dotyczące emerytur ${ }^{43}$. Aby ją otrzymywać, uprawniony musiał mieszkać w dobrach sztabińskich. Mógł zostać w każdej chwili wezwany przez administratora do powrotu do służby, która musiała odpowiadać jego sile i zdolnościom. Za powrót do służby otrzymywano takie samo wynagrodzenie, jakie pobierano przed przejściem na emeryturę. Wdowa otrzymywała $1 / 4$ emerytury, jaką pobierałby jej zmarły mąż, natomiast dziecko do lat piętnastu 1/10 emerytury, jaka przypadałaby zmarłemu ojcu. Prawo do emerytury nie przysługiwało, gdy uprawnionemu zostały „sądownie udowodnione jakiekolwiek fałsze i przeniewierzenie się” oraz gdyby posiadał fundusz, przynoszący co najmniej tyle dochodu, ile przypadające na niego świadczenie ${ }^{44}$.

Hrabia chciał, aby zakłady przemysłowe dóbr sztabińskich funkcjonowały po jego śmierci. Świadczy o tym krótkie zdanie, zamieszczone w testamencie: „Fabryki istnieć mają ${ }^{\text {”25 }}$. Przy zakładach przemysłowych miały nadal działać szkółki dla dzieci i terminatorów. W przypadku, gdyby zastój w fabryce trwał dłużej niż sześć miesięcy, robotnicy mieli otrzymywać połowę swojego wynagrodzenia. Administrator mógł skasować fabrykę dopiero po upływie pięciu lat, w trakcie których buchalteria dworska stwierdzałaby nierentowność zakładu.

Dochód Instytucji Rolno-Fabrycznej Sztabińskiej, na mocy testamentu Brzostowskiego, miał być dzielony na cztery części ${ }^{46}$. Część pierwsza miała być przeznaczona na coroczne podwyższanie funduszu Instytucji; część kolejna została przyznana administratorowi do jego sumiennej dyspozycji. Brzostowski rozumiał przez to m.in. udzielanie wsparcia ubogim. Natomiast dwie ostatnie części miały stanowić wynagrodzenie dla administratora i jego rodziny.

Należy zadać pytanie, w oparciu o jaką podstawę prawną Karol Brzostowski utworzył Instytucję Rolną-Fabryczną Sztabińską? W testamencie nie powołał

\footnotetext{
43 Ibidem.

44 Ibidem.

45 Ibidem.

46 Ibidem, s. 6 .
} 
się na żaden akt prawny, jednak zawarł w nim bardzo istotną klauzulę: „Nie będąc dosyć obeznany z prawem, może być, że niektóre myśli i żądania moje, tu wypisane, nie będą uznane za prawne; żądam przeto, aby w razie sądowego rozpoznania takowych, kondycya i zastrzeżenia moje, które uważane będą za nieprawne, nie znosiły głównej mojej intencji jako Testatora..." ${ }^{\text {"47 }}$. Umieszczenie takiej wypowiedzi w testamencie było bardzo rozsądne ze strony Brzostowskiego. Hrabia przeczuwał, że po jego śmierci będą podejmowane próby unieważnienia jego ostatniej woli. Dzięki temu fragmentowi nawet, gdyby się to udało, to główna intencja hrabiego, czyli zapewnienie źródła dochodu włościanom sztabińskim, zostałaby utrzymana.

30 marca 1855 r. Rada Administracyjna Królestwa Polskiego uregulowała tytuł własności majątku pod nazwą: „Gmina dóbr Sztabin jako Instytucja rolniczo-fabryczna, fundacyi ś. p. Karola hr. Brzostowskiego, składająca się z Włości i Funduszu Fabryk" ${ }^{\prime 48}$. Rada Administracyjna stwierdziła, że postanowienia testamentowe nie są sprzeczne z art. 910 Kodeksu cywilnego (tzw. Kodeks Napoleona), który stanowił, że „...rozporządzenia między żyjącemi, albo przez testament, na korzyść Szpitalów, ubogich, gminu lub ustanowienia do publicznego dobra zmierzającego, tyle tylko swóy skutek mieć będą, ile wyrokiem Cesarskim upoważnione zostaną ${ }^{\text {'49 }}$.

Do testamentu został dołączony dodatek ${ }^{50}$. Testator mianował $\mathrm{w}$ nim administratorem Adolfa Gerschoffa - inżyniera guberni warszawskiej, którego poznał w trakcie budowy Kanału Augustowskiego. Brzostowski obdarował również osoby, które opiekowały się nim podczas choroby: Otylię Neuman, Juliannę Krzyżewską oraz Fridricha Gerocha. Najemnikom bez gruntu i domostwa, którzy pracowali w folwarku cisowskim, testator przyznał jednorazowo średni, miesięczny zarobek. W dodatku zawarta była również lista osób zasłużonych, których nie mógł zwalniać administrator.

Drukarnia Aleksandra Girsa opublikowała testament podróżny Brzostowskiego, napisany w Cisowie 12 grudnia 1853 r., kilka dni przed wyjazdem do Królewca $^{51}$. Nie mogła tego uczynić drukarnia Józefa Ungera w 1855 r., ponieważ dopiero w 1862 r. regent kancelarii ziemiańskiej guberni augustowskiej Teofil Józef Kowalski potwierdził zgodność testamentu podróżnego, napisanego w języku francuskim $z$ jego polskim odpowiednikiem ${ }^{52}$. Testament podróżny został sporządzony w dwóch egzemplarzach: po polsku i po francusku ${ }^{53}$.

47 Ibidem, s. 8 .

48 Ibidem, s. 11.

49 Kodex Napoleona z przypisami. Xiag trzy, [w:] Biblioteka Cyfrowa Uniwersytetu Wrocławskiego, s. 121.

50 Testament Karola Hr. Brzostowskiego - wypis urzędowy, s. 10.

51 Ibidem, s. 13-14.

52 Ibidem, s. 13.

53 Ibidem, s. 11. 
Testament $\mathrm{w}$ języku polskim mógł znajdować się w Cisowie, natomiast drugi egzemplarz zapewne został zabrany w podróż przez Brzostowskiego. Testament w języku francuskim zawierał dodatkowe rozporządzenia, które Brzostowski umieścił, będąc już na obczyźnie.

Zgodnie z treścią testamentu podróżnego Otylia Neuman, która towarzyszyła Brzostowskiemu w podróży, została zobligowana do poniesienia kosztów pogrzebu z pieniędzy, które hrabia miał przy sobie. Obowiązkiem Neuman był również powrót do Cisowa po pogrzebie Brzostowskiego i zdanie rachunku z pieniędzy i papierów, które posiadał zmarły. Karol Brzostowski przyznał Otylii Neuman wszystkie swoje rzeczy podróżne oraz dziesięć tysięcy rubli z listów zastawnych Towarzystwa Kredytowego Ziemskiego. 22 marca 1854 r., będąc we Francji i spodziewając się śmierci, Brzostowski dopisał w testamencie kolejną dyspozycję, w której podarował sześć tysięcy rubli Jerzemu Białopiotrowiczowi. Obowiązkiem obdarowanego było wybranie miejsca pochówku hrabiego. Białopiotrowicz został również mianowany egzekutorem testamentu podróżnego ${ }^{54}$.

Instytucja Rolno-Fabryczna Sztabińska interesowała badaczy już w II połowie XIX w. W 1860 r. dobra Instytucji odwiedził Ludwik Pietrusiński - znany podróżnik oraz prawnik. Gość miał okazję przeglądać dokumenty i księgi rachunkowe, znajdujące się w kancelarii dworskiej. Jego spostrzeżenia zostały zawarte w książce Krasnybór czyli Sztabin i Karol Hr. Brzostowski ${ }^{55}$. Losy dziedzictwa Brzostowskiego interesowały również księdza Jakóba Rółkowskiego proboszcza sztabińskiej parafii w latach 1901-1941. W swojej autobiograficznej książce Trzydzieści lat mego pasterzowania w parafii sztabińskiej wiele miejsca poświęcił opisom starań o ratowanie majątku Instytucji w okresie zaborów i dwudziestolecia międzywojennego ${ }^{56}$. Najwięcej na temat biografii Karola Brzostowskiego oraz początków funkcjonowania Instytucji napisał profesor Julian Bartyś w wydanej w 1978 r. książce Czerwony Hrabia Karol Brzostowski ${ }^{57}$. Julian Bartyś, widząc w Brzostowskim prekursora socjalizmu w Polsce, unikał w swoim dziele tematów, które mogły ugodzić w wizerunek władzy ludowej. Dlatego też bardzo pobieżnie zbadał losy dziedzictwa Brzostowskiego w II Rzeczypospolitej. W tamtym okresie najaktywniejszym działaczem, starającym się ratować majątek Instytucji, był wspomniany proboszcz Rółkowski. Ksiądz bardzo krytycznie pisał o Rosji Sowieckiej i na stronach swojej autobiograficznej książki radował się ze zwycięstwa w Bitwie Warszawskiej ${ }^{58}$. Julianowi Bartysiowi nie zależało na tym, aby takie publikacje cieszyły się zainteresowaniem

54 Ibidem, s. 14.

55 L. Pietrusiński, op. cit.

56 J. Rółkowski, Trzydzieści lat mego pasterzowania w parafii sztabińskiej, Szczecin 2019.

57 J. Bartyś, op. cit.

58 J. Rółkowski, op. cit., s. 160. 
w społeczeństwie. Na temat Instytucji Rolno-Fabrycznej Sztabińskiej pisali również m.in.: Grzegorz Ryżewski ${ }^{59}$, Stefan Maciejewski ${ }^{60}$, Irena Wanda Kosmowska $^{61}$ oraz Halina Zawistowska-Zacharewicz ${ }^{62}$.

Karol Brzostowski trafnie przewidział, że po jego śmierci pojawią się osoby, chcące unieważnić jego testament. Tą osobą była jego rodzona siostra Izabela. W 1855 r. hrabianka wniosła pozew przeciwko Adolfowi Gerschoffowi. Przedstawiła następujące roszczenia ${ }^{63}$ :

1. Roszczenie o uznanie za nieważne jej oświadczenia woli z 15 czerwca 1836 r., w którym zrzekła się współwłasności dóbr sztabińskich;

2. Roszczenie o uznanie za symulowane i nieprawne nabycia własności dóbr sztabińskich przez Antoniego Kruszewskiego w dniu 14 listopada 1849 r.;

3. Roszczenie o uznanie na nieważną części testamentu Karola Brzostowskiego z dnia 29 listopada 1853 r., która dotyczyła Instytucji Rolno-Fabrycznej Sztabińskiej oraz dodatku do tego testamentu, ponieważ testator, zdaniem hrabianki, dysponował cudzą własnością. Brzostowska uważała, że ustanowienie Instytucji nie odpowiadało wyobrażeniu gminy z art. 542 Kodeksu cywilnego (tzw. Kodeks Napoleona), który stanowił, że „gminne dobra są te, do których własności lub przychodów nabyli prawa mieszkańcy gminy" ${ }^{\text {"2 }}$. Dlatego też hrabianka uważała, że dyspozycja testamentowa została dokonana na rzecz nieoznaczonej lub nieistniejącej osoby prawnej ${ }^{65}$;

4. Roszczenie o przywrócenie prawa własności całych dóbr sztabińskich na rzecz Izabeli Brzostowskiej wraz z dobrodziejstwem inwentarza.

W lipcu 1856 r. Trybunał Cywilny Guberni Warszawskiej orzekł o nieważności ostatniej woli testatora i przyznał prawo własności dóbr siostrze zmarłego ${ }^{66}$. Apelację od wyroku złożyli: Prokuratoria Generalna Królestwa Kongresowego, Antoni Kruszewski oraz Adolf Gerschoff. Administratora Instytucji reprezentował znany warszawski adwokat Franciszek Ksawery Kojsiewicz. Brzostowska, uzasadniając swoje roszczenie, twierdziła, że brat wywierał na nią nacisk

59 G. Ryżewski, op. cit.

60 S. Maciejewski, op. cit.

61 I. W. Kosmowska, op. cit.

62 H. Zawistowska-Zacharewicz, Działalność społeczno-gospodarcza i oświatowa Karola Brzostowskiego ze Sztabina koło Augustowa, [w:] Studia i materiały do dziejów pojezierza augustowskiego, red. J. Antoniewicz, Białystok 1967.

63 F.K. Kojsiewicz, Adolf Gerschoff administrator testamentowy dóbr i fabryk Sztabin i Krasnybór w Krasnymboru Okręgu Dąbrowskim Gubernii Augustowskiej mieszkający, appellujący przez Xawerego Kojsiewicza stawiający wnosi, Warszawa 1857, s. 1-2.

64 Kodex Napoleona z przypisami. Xiag trzy, [w:] Biblioteka Cyfrowa Uniwersytetu Wrocławskiego, s. 146.

65 Wywód apelacyjny Prokuratoryi w Królestwie Polskiem na rzecz gminy dóbr Sztabin i Krasnybór, czyli Instytucyi rolniczo-fabrycznej czyniącej przeciwko Izabelli hrabiance Brzostowskiej o ważności Testamentu śp. Karola hr. Brzostowskiego, Warszawa 1857, s. 57.

66 F.K. Kojsiewicz, Adolf Gerschoff, s. 1-2. 
moralny oraz podstępem zmusił ją do złożenia oświadczenia o zrzeczeniu się współwłasności ${ }^{67}$. Pełnomocnik Gerschoffa przytoczył treść oświadczenia woli Brzostowskiej z 15 czerwca 1836 r., w którym hrabianka napisała: „... kontentując się nadal pensyą roczną dożywotnią po złp. 5,000 którą waruję sobie; interesa wszelkie dotąd spólne nasze, na brata naszego przelewam całkowicie" ${ }^{\prime 68}$. Adwokat zacytował również list Izabeli do brata, napisany 29 października 1853 r.,w którym hrabianka stwierdziła: „Moje interesa dobrze idą; procent odbieram najregularniej, jestem zupełnie kontenta i chciałbym kiedyś osobiście podziękować za to bratu" ${ }^{\prime 69}$. Zdaniem Kojsiewicza z zacytowanych fragmentów nie wynikało, aby Brzostowski w jakiś sposób wpływał na postępowanie siostry. Mecenas nie zgodził się również z kolejnym roszczeniem Izabeli Brzostowskiej, która uważała, że nabycie dóbr sztabińskich przez Antoniego Kruszewskiego było symulowane i nieprawne. Kojsiewicz wypomniał siostrze testatora, że za życia Brzostowskiego nigdy nie protestowała przeciwko dokonaniu wspomnianej czynności prawnej, skupiając się jedynie na pobieraniu rocznej pensji ${ }^{70}$.

Izabela Brzostowska uważała, że dyspozycje testamentowe jej brata były „dziwaczne w czasie chorobliwym wymarzonemi" ". Dotyczyło to np. możliwość utraty prawa własności ziemi przez chłopa z powodu pijaństwa. Zdaniem hrabianki było to przeciwne dobrym obyczajom i porządkowi publicznemu. Kojsiewicz odpowiedział Brzostowskiej w następujący sposób: „Nadzwyczajnemi przecież nie są te rygory i warunki, bo cóż od nich wymaga? Zachowania się takiego, jak się sam $\mathrm{z}$ dobrej woli zachował i co każdemu jako konieczny warunek życia zachowywać jego własna jakakolwiek wiara nakazuje”72. Hrabianka uważała również, że część postanowień testamentowych była „niepraktycznemi, w wykonaniu trudnemi, w rozporządzeniach niestosownemi, z chorobliwej niechęci dla siostry na wyzucie jej z praw wymyślonemi”. Miała przy tym na myśli np. wymagania, nałożone na administratora przez Brzostowskiego. Prokuratoria Generalna Królestwa Polskiego, którą reprezentowali Antoni Przeszkodziński i Włodzimierz Podhorecki, nie zgadzając się z opinią hrabianki, stwierdziła, że,jeżeli dziś do prowadzenia gospodarstwa rolnego potrzeba zamiłowania, nauki, pracy i wytrwałości, które tylko interes osobisty w czynności utrzymać zdoła; to do kierowania znakomitemi fabrykami w wyższym jeszcze stopniu przymioty te są potrzebne"73. Na roszczenie

67 Wywód apelacyjny Prokuratoryi w Królestwie Polskiem na rzecz gminy dóbr Sztabin i Krasnybór, czyli Instytucyi rolniczo-fabrycznej czyniacej przeciwko Izabelli hrabiance Brzostowskiej o ważności Testamentu śp. Karola hr. Brzostowskiego, Warszawa 1857, s. 37.

68 F.K. Kojsiewicz, Adolf Gerschoff, s. 12.

69 Ibidem, s. 17.

70 Ibidem, s. 18.

71 Ibidem, s. 19.

72 Idem, Odpowiedź Adolfa Gerschoff na skargę Izabelli hrabianki Brzostowskiej, Warszawa 1858, s. 19-22 .

73 Wywód apelacyjny Prokuratoryi..., s. 64-65. 
powódki, że Instytucja Rolno-Fabryczna Sztabińska nie jest gminą w rozumieniu art. 542 Kodeksu cywilnego, Prokuratoria Generalna Królestwa Polskiego odpowiedziała, że gmina sztabińska istniała jeszcze przez śmiercią Brzostowskiego oraz, że majątek Funduszu wypełnia przesłanki majątku gminy, zgodnie z treścią art. 542 Kodeksu cywilnego ${ }^{74}$.

Działania apelujących przyniosły zamierzony skutek, ponieważ Sąd Apelacyjny w lipcu 1857 r. utrzymał testament w mocy. Izabela Brzostowska była niestrudzona i odwołała się do Senatu Cesarstwa Rosyjskiego, który 18 listopada $1858 \mathrm{r}$. oddalił jej skargę kasacyjną ${ }^{75}$. W sentencji wyroku zawarto następujące uzasadnienie: „Nie można utrzymywać (...), iżby tak zwany przez testatora fundusz fabryczny był zapisany osobie nieoznaczonej lub nieistniejącej, gdyż stanowi on zapis, czyli fundusz na korzyść gminy Sztabin, istniejącej już przed śmiercią testatora"76. Siostra zmarłego poszukiwała wsparcia u samego cara, jednak 29 maja 1862 r. sekretarz stanu, w imieniu monarchy, nie przyznał racji jej roszczeniom ${ }^{77}$. Hrabianka próbowała również udowodnić, że Karol Brzostowski prześladował oraz zmuszał okolicznych włościan do niewolniczej pracy. W 1860 r. część chłopów sztabińskich na polecenie Izabeli Brzostowskiej stwierdziła, że hrabia karał wygórowanymi opłatami do karbonek wiejskich oraz zmuszał do pracy na rzecz dworu za matym i nieodpowiednim wynagrodzeniem ${ }^{78}$. Jednak dwa lata później hrabianka zaprzeczyła sama sobie. 13 lutego 1862 r. oficjaliści dworscy: Wierzbicki, Ussakowski oraz Bartoszewicz, działający na rzecz siostry testatora, napisali pismo do Rady Stanu Królestwa Polskiego, w którym skarżyli się na poczynania administratora Adolfa Gerschoffa oraz jego następcy Henryka Muklanowicza. Chcąc zaszkodzić administratorom stwierdzili, że za życia Brzostowskiego „włościanie nie znali żadnych sądów, procesów, ani nawet drogi do nich nie wiedzieli”. Napisali, że sprawiedliwość była wymierzana „na miejscu" ${ }^{79}$. Oczernianie zmarłego testatora przez jego siostrę pokazuje jedynie, jak cyniczną osobą była Izabela Brzostowska. Hrabianka mogła powiedzieć o bracie wszystko, byleby tylko uzyskać korzyść finansową. Wszystkie jej starania zostały załatwione negatywnie, ponieważ Dyrektor Główny Komisji Rządowej Spraw Wewnętrznych oraz Komisja Rządowa Sprawiedliwości opowiedzieli się przeciwko jej roszczeniom ${ }^{80}$.

Upadek znaczenia Instytucji Rolno-Fabrycznej nastąpił już kilka lat po wejściu w życie testamentu. Nowy administrator Adolf Gerschoff nie spełnił

74 Ibidem, s. 63.

75 AGAD, III RS, Akta dotyczace memoriałów Izabelli hr. Brzostowskiej o przywrócenie do posiadania dóbr Sztabin [w gub. suwalskiej] niegdyś do matki jej należących, sygn. 299, s. 48.

76 Ibidem, s. 49.

77 Ibidem, s. 284-286.

78 J. Bartyś, op. cit., s. 278.

79 AGAD, III RS, sygn. 299, s. 84-85.

80 J. Bartyś, op. cit., s. 459. 
pokładanych w nim nadziei. Rozpoczął się konflikt na linii administrator włościanie. Chłopi sztabińscy zarzucali Gerschoffowi niespełnianie następujących wymagań, jakie na administratora nałożył w testamencie Karol Brzostowski:

1. Obowiązkiem administratora było posiadanie wykształcenia technika i inżyniera oraz umiejętność osobistego poprowadzenia fabryk, które znajdowały się pod jego zarządem ${ }^{81}$. Adolf Gerschoff był z wykształcenia inżynierem geodetą, jednak w ogóle nie interesował się sposobem działania zakładów Huty Sztabińskiej. Symbolem niekompetencji Gerschoffa było rozbicie na złom, wybudowanej przez Karola Brzostowskiego, maszyny parowej oraz zlikwidowanie telegrafu, który uznał za pańska fantazje $e^{82}$

2. Administrator został zobligowany do stałego zamieszkiwania na terenie dóbr ${ }^{83}$. Natomiast Gerschoff mieszkał w Warszawie, rzadko odwiedzając ziemię sztabińską;

3. W dodatku do testamentu Karol Brzostowski zawarł listę zasłużonych współpracowników, którzy mieli mieć zagwarantowaną pracę po jego śmierci ${ }^{84}$. Wbrew intencjom testatora, Adolf Gerschoff zwolnił najbliższego współpracownika hrabiego - Marcina Sztukowskiego, rok przed wysłużeniem przez niego dwudziestu lat, co dawałoby mu prawo do wyższej emerytury.

Chłopi mieli również pretensję do administratora o sprzeniewierzenie przez niego pieniędzy z kasy Fundacji oraz prowadzenie niekontrolowanej wycinki lasów, która miała miejsce od $1858 \mathrm{r} .^{85}$ Włościanie sztabińscy, uzasadniając swoje roszczenia przeciwko Gerschoffowi, powoływali się na treść testamentu Karola Brzostowskiego, który stanowił: „Nie mający tych kwalifykacyj lub niedotrzymujący tych warunków [wymagań nałożonych na administratora przyp. M.U.], ma być [administrator - przyp. M.U.] na czyjekolwiek bądź wezwanie lub oskarżenie przez Sądy zwyczajne Cywilne od wszelkich praw do tej Administracyj, z mocy niniejszego Testamentu nadanej, raz na zawsze odsądzony" ${ }^{\prime \prime}$.

W odwecie Gerschoff obniżył pensje wypłacane pracownikom oraz zarządził nowy pomiar dóbr, przez co gospodarstwa chłopskie uległy zmniejszeniu. Doprowadziło to do bardzo komicznej sytuacji w grudniu $1858 \mathrm{r}$., kiedy to Gerschoff wraz z dworzanami najechał konno okoliczne łąki, chcąc odebrać chłopom ułożone stogi siana. Administrator twierdził, że zebrana

81 Testament Karola Hr. Brzostowskiego - wypis urzędowy, s. 5.

82 J. Bartyś, op. cit., s. 317.

83 Testament Karola Hr. Brzostowskiego - wypis urzędowy, s. 5.

84 Ibidem, s. 10.

85 J. Bartyś, op. cit., s. 316.

86 Testament Karola Hr. Brzostowskiego - wypis urzędowy, s. 4. 
pasza jest własnością dworu, ponieważ według dokonanego przez niego pomiaru dóbr, wspomniane łąki nie były własnością chłopską ${ }^{87}$. Spór pomiędzy Gerschoffem a włościanami zainteresował Prokuratorię Generalną Królestwa Polskiego. Dlatego też latem 1860 r. do Cisowa przyjechał radca Prokuratorii - Ludwik Pietrusiński. Miał on za zadanie ocenić słuszność skarg włościan, kierowanych pod adresem administratora ${ }^{88}$. Jednak już kilka miesięcy później, we wrześniu $1860 \mathrm{r}$. Adolf Gerschoff odszedł z tego świata.

Należy w tym miejscu zadać pytanie, dlaczego Karol Brzostowski popełnił tak duży błąd w wyborze administratora Instytucji Rolno-Fabrycznej Sztabińskiej? Jest to tym bardziej zdumiewające, że znał Gerschoffa od ponad trzydziestu lat. Starając się odpowiedzieć na postawione pytanie, trzeba napisać kilka słów o charakterze Karola Brzostowskiego. Hrabia był człowiekiem bardzo pracowitym, wymagającym od siebie i od swoich oficjalistów. Całkowite poświęcenie przez niego życia prywatnego na rzecz kierowania dobrami sztabińskimi spowodowało, że nie założył rodziny oraz nie znalazł godnego następcy. Brzostowski był wizjonerem, jednak większość osób z jego otoczenia kierowała się własnymi interesami. Właśnie takim człowiekiem był Adolf Gerschoff, który z pozoru mógł wydawać się dobrym kandydatem na administratora, lecz w rzeczywistości jawnie przyczynił się do upadku znaczenia Instytucji. Krytykując Gerschoffa, jednego nie można mu zarzucić - w sporze z Izabelą Brzostowską $\mathrm{z}$ dużym zaangażowaniem starał się wykazać bezpodstawność jej roszczeń. Administrator robił to jednak nie z powodów ideowych, lecz chciał zagwarantować sobie stałe źródło utrzymania, jakim był dochód Instytucji.

Schorowany Adolf Gerschoff mianował swoim następcą syna Edwarda. Brzostowski nie zabronił administratorom Instytucji wyznaczać na to stanowisko osób z nimi spokrewnionych ${ }^{89}$. Ponieważ syn nie miał ukończonych dwudziestu pięciu lat, administratorem Instytucji został kurator Edwarda - Henryk Muklanowicz ${ }^{90}$. Prawą ręką Muklanowicza był kasjer o nazwisku Panasiewicz ${ }^{91}$. Nowy administrator okazał się jeszcze bardziej zachłannym na pieniądze od swojego poprzednika ${ }^{92}$. W kwietniu $1861 \mathrm{r}$. w tajemniczych okolicznościach spłonął magazyn surowców i wyrobów fabryki maszyn i narzędzi rolniczych. Interwencja w tej sprawie Prokuratorii Generalnej Królestwa Polskiego spowodowała dymisję Henryka Muklanowicza ${ }^{93}$. Również Ministerstwo Spraw Wewnętrznych Cesarstwa Rosyjskiego wmieszało się w spór pomiędzy włościana-

$\overline{87}$ AGAD, III RS, sygn. 299, str. $134-135$.

88 Ibidem, s. 106, 138.

89 Testament Karola Hr. Brzostowskiego - wypis urzędowy, s. 3-4.

90 Ibidem, s. 34.

91 H. Zawistowska-Zacharewicz, op. cit., s. 459.

92 J. Bartyś, op. cit., s. 320.

93 Ibidem, s. 320. 
mi a administratorem, czego efektem stała się niemożność wydawania uchwał przez Instytucję bez zatwierdzenia i upoważnienia Komitetu Urządzającego do spraw włościańskich ${ }^{94}$. Bardzo ograniczyło to niezależność Instytucji. Niezatwierdzone zostały uchwały, dotyczące m.in. prowadzenia szkół; wypłaty wynagrodzeń i emerytur. Było to przejawem postępującej rusyfikacji, w szczególności w kwestii ograniczania rozwoju szkolnictwa. Zaborca rosyjski nie chciał, aby na ziemi sztabińskiej istniał sprawny samorząd gminy.

Kolejnym administratorem Instytucji został, na wyraźne żądanie włościan, Marcin Sztukowski. Pomimo usilnych starań Sztukowskiemu nie udało się uruchomić nieczynnych zakładów i spłacić zadłużenia. Czy było to efektem niekompetencji Sztukowskiego? Należy postawić tezę, że nie. Marcin Sztukowski miał wszelkie predyspozycje do tego, żeby właściwie pokierować Instytucją, jednak z powodu zaniedbań Gerschoffa i Muklanowicza było już za późno na uratowanie majątku. Od roku 1880 dobra Instytucji znalazły się pod bezpośrednim zarządem Ministerstwa Spraw Wewnętrznych Cesarstwa Rosyjskiego ${ }^{95}$. W 1883 r. rząd rosyjski wystawił wspomniany majątek na sprzedaż, z wyjątkiem 2200 morgów lasu, które pozostawiono dzięki inicjatywie wójta gminy Sztabin Teofila Neufeldta ${ }^{96}$. Nabywcą majątku została księżna Anna Michałowska-Szachowska. Nowa właścicielka wyprzedała cały inwentarz żywy, wszystkie narzędzia gospodarskie oraz wycinała lasy. W 1885 r. fundusz Brzostowskiego składał się z: kapitału 136000 rubli w listach zastawnych, 200000 rubli wpłaconych przez Szachowską oraz ze wspomnianego lasu, który określany był mianem Parcelacji Sztabińskiej ${ }^{97}$. W 1886 r. księżna wydzierżawiła cały majątek Józefowi Górskiemu ${ }^{98}$. W 1909 r., za pośrednictwem rosyjskiego Banku Ziemskiego, zlicytowano cały majątek Szachowskiej. Około 20\% licytowanych gruntów zakupili mieszkańcy ziemi sztabińskiej. Fundusz Brzostowskiego, wynoszący około 600000 rubli, został przelany na konto gminy Sztabin, który ulokowano w warszawskim oddziale Banku Państwowego ${ }^{99}$. Z tych pieniędzy wybudowano: cztery szkoły podstawowe, neogotycki kościół pw. św. Jakuba Apostoła w Sztabinie oraz oddział pocztowo-telegraficzny. Pieniądze, pochodzące z Funduszu, posłużyły także do przeprowadzenia robót melioracyjnych ${ }^{100}$.

Jeszcze w trakcie I wojny światowej zarząd Parcelacją przejęła gmina. Zarządem kierował ksiądz Rółkowski ${ }^{101}$. Dzięki jego interwencji wojska niemieckie, okupujące Suwalszczyznę w latach 1915-1919, nie wycinały drzew z lasów

\footnotetext{
94 I.W. Kosmowska, op. cit., s. 30.

95 Ibidem, s. 31.

96 J. Bartyś, op. cit., s. 323.

97 Ibidem, s. 30.

98 Ibidem, s. 324.

99 Ibidem.

100 Ibidem, s. 326.

101 J. Rółkowski, op. cit., s. 163-163.
} 
Fundacji $^{102}$. W niepodległej Polsce w 1922 r. utworzono organ zarządzający lasami Parcelacji o nazwie Komisja Leśna. Powstała ona dzięki inicjatywie starosty augustowskiego Wacława Malanowskiego ${ }^{103}$. Jej zadaniem było kontrolowanie racjonalnego gospodarstwa leśnego oraz sprzedaż drewna w drodze licytacji. Uzyskane dochody przeznaczano na pożyczki, zapomogi i stypendia dla uczniów.

Plany gospodarstwa leśnego opracowywał w gminie Sztabin sekretarz o nazwisku Zambrowicz. Jeden z mieszkańców ziemi sztabińskiej, którego imienia i nazwiska nie ujawnił Jakób Rółkowski, napisał na sekretarza skargę o nieznanej dotąd treści. Skarga dotyczyła najprawdopodobniej nieprawidłowości, jakich miał dopuścić się Zambrowicz przy zarządzaniu Parcelacją Sztabińską. Adresatem skargi został poseł na Sejm Rzeczypospolitej Polskiej Karol Polakiewicz ze Stronnictwa Chłopskiego ${ }^{104}$. Poseł poinformował o skardze ministra spraw wewnętrznych. Wydaje się, że Karol Polakiewicz uczynił to słownie lub za pomocą korespondencji prywatnej, ponieważ nie zachowała się żadna interpelacja poselska lub wniosek, sporządzony w tej sprawie przez posła Polakiewicza. Minister spraw wewnętrznych kazał wojewodzie białostockiemu Marianowi Rembowskiemu zainterweniować w sprawie domniemanych malwersacji. $\mathrm{Z}$ tego powodu w Sztabinie pojawił się inspektor samorządu ${ }^{105}$. Przybyły gość, nieumiejętnie interpretując testament Karola Brzostowskiego, uznał, że Parcelacją Sztabińską winien zarządzać administrator, a nie gmina. Bardzo krytycznie odniósł się do tej opinii ksiądz Jakób Rółkowski. Duchowny powiedział inspektorowi, że administrator był potrzebny, gdy istniały fabryki i zakłady przemysłowe. Dodał również, że na utrzymanie administratora nie wystarczy dochodów z lasów Fundacji ${ }^{106}$. Ograniczanie niezależności Fundacji zaczęło się w czerwcu 1926 r., kiedy to w asyście policji przyjechał do Sztabina starosta augustowski Wacław Malanowski i zabrał wszystkie pieniądze oraz dokumenty, dotyczące Parcelacji ${ }^{107}$. W 1930 r. nadzór nad lasami przejęła Rada Fundacyjna oraz administrator, wyznaczany przez Ministerstwo Spraw Wewnętrznych ${ }^{108}$. Pierwszym administratorem był Wacław Zagórski, którego zastąpił w 1934 r. Stanisław Kulczycki. W latach trzydziestych, przede wszystkim dzięki zyskom z Parcelacji, wybudowano szkołę powszechną w Sztabinie ${ }^{109}$. Kwestia zarządzania Parcelacją Sztabińską w II Rzeczypospolitej została opisana głównie przez

102 Ibidem, s. 163.

103 Ibidem, s. 173.

104 Ibidem, s. 175.

105 Ibidem.

106 Ibidem, s. 192.

107 Ibidem, s. 177.

108 J. Bartyś, op. cit., s. 326.

109 G. Ryżewski, op. cit., s. 223. 
księdza Rółkowskiego. Wymaga ona dalszych badań, w szczególności analizy materiałów archiwalnych.

W pierwszych latach Polski Ludowej lasami Fundacji administrowała gmina ${ }^{110}$. Na mocy Ustawy z 18 listopada 1948 r. o przejściu na własność Państwa niektórych lasów i innych gruntów samorządowych pozostałości Instytucji Sztabińskiej stały się własnością Państwa ${ }^{111}$. Taki był los dziedzictwa Karola Brzostowskiego.

Instytucja Rolno-Fabryczna Sztabińska miała za zadanie zapewnić stałe źródło utrzymania dla wychowanków Karola Brzostowskiego. Niestety, jego szlachetne idee zostały za jej pomocą zrealizowane w niewielkim stopniu. Są to przede wszystkim zabytki architektoniczne, np. neogotycki kościół w Sztabinie, którego budowa została sfinansowana z Funduszu Brzostowskiego. Do dzisiaj hrabia jest darzony szacunkiem przez mieszkańców Sztabina, czego przejawem jest m.in. działalność Towarzystwa Przyjaciół Ziemi Sztabińskiej im. Karola Brzostowskiego. Instytucja Rolno-Fabryczna Sztabińska stanowi bardzo ciekawy obszar badań, dający możliwość poszerzenia wiedzy na temat wielu gałęzi prawa.

\section{Bibliografia}

\section{Źródła}

AGAD, III RS, Akta dotyczące memoriałów Izabelli hr. Brzostowskiej o przywrócenie do posiadania dóbr Sztabin [w gub. suwalskiej] niegdyś do matki jej należących, sygn. 299.

Kodex Napoleona z przypisami. Xiagg trzy, [w:] Biblioteka Cyfrowa Uniwersytetu Wrocławskiego.

Kojsiewicz F.K., Adolf Gerschoff administrator testamentowy dóbr i fabryk Sztabin i Krasnybór w Krasnymboru Okręgu Dąbrowskim Gubernii Augustowskiej mieszkajacy, appellujący przez Xawerego Kojsiewicza stawiajacy wnosi, Warszawa 1857.

Kojsiewicz F.K., Odpowiedź Adolfa Gerschoff na skargę Izabelli hrabianki Brzostowskiej, Warszawa 1858.

Komitet Narodowy Komitet jako tymczasowy Rzad Narodowy [Inc.: Zważywszy, że uwłaszczenie włościan pomimo ogólnej chęci kraju, z powodu stawianych przez Rzad Najezdniczy przeszkód dotąd do skutku nie doszło - obok tego...], Warszawa 1863.

Postanowienie Cesarza Wszech Rosji, Króla Polskiego z dnia 23 lutego 1837 r., Dziennik Praw Królestwa Polskiego, t. 20, nr 68-70, s. 413-417.

110 M. Sidor, Karol hrabia Brzostowski i jego dobra - źródła w zbiorach Archiwum Państwowego w Suwatkach, http://www.astn.pl/r2004/zrodla.htm

111 Dz.U. nr 57, poz. 455 i 456. 
Postanowienie Namiestnika Królestwa Polskiego z dnia 16 stycznia 1816 r., Dziennik Praw Królestwa Polskiego, t. 1, nr 1-7, s. 115-120.

Testament Karola Hr. Brzostowskiego - wypis urzędowy, drukarnia Alexandra Ginsa, Warszawa 1862.

Ukaz o urządzeniu Włościan, Dziennik Praw Królestwa Polskiego, t. 62, nr 187-193.

Ustawa z dnia 18 listopada 1948 r. o przejściu na własność Państwa niektórych lasów i innych gruntów samorządowych, (Dz.U. nr 57, poz. 455 i 456).

Włościanom ze wsi Sztabina odpowiedz Redakcji, „Tygodnik Suwalski” 1908 (18 września), nr 38, s. 5-6.

Wypis urzędowy testamentu ś. p. Karola Hr. Brzostowskiego, drukarnia Józefa Ungera, Warszawa 1855.

Wywód apelacyjny Prokuratoryi $w$ Królestwie Polskiem na rzecz gminy dóbr Sztabin i Krasnybór, czyli Instytucyi rolniczo-fabrycznej czyniącej przeciwko Izabelli hrabiance Brzostowskiej o ważności Testamentu ś. p. Karola hr. Brzostowskiego, Warszawa 1857.

\section{Opracowania}

Bartyś J., Czerwony Hrabia Karol Brzostowski, Warszawa 1978.

Grabski W., Historia Towarzystwa Rolniczego: 1858-1861 r., t. 2, Warszawa 1904.

Kosmowska I. W., Karol Brzostowski, [w:] Maqdrzy gospodarze, Warszawa 1917.

Maciejewski S., Szlachetni pasjonaci, Olsztyn 1978.

Pietrusiński L., Krasnybór czyli Sztabin i Karol Hr. Brzostowski, Warszawa 1863, Sztabin 1991.

Połujański A., Opisanie lasów Królestwa Polskiego i Guberni Zachodnich Cesarstwa Rosyjskiego pod względem historycznym, statystycznym i gospodarczym, t. 1, Warszawa 1854.

Rółkowski J., Trzydzieści lat mego pasterzowania w parafii sztabińskiej, Szczecin 2019.

Ryżewski G., Dzieje obszarów gminy Sztabin od czasów najdawniejszych do współczesności, Białystok-Sztabin 2002.

Sidor M., Karol hrabia Brzostowski i jego dobra - źródła w zbiorach Archiwum Państwowego w Suwałkach, [w:] http://www.astn.pl/r2004/zrodla.html

Zawistowska-Zacharewicz H., Działalność społeczno-gospodarcza i oświatowa Karola Brzostowskiego ze Sztabina koło Augustowa, [w:] Studia i materiały do dziejów pojezierza augustowskiego, red. J. Antoniewicz, Białystok 1967. 


\section{STRESZCZENIE}

Na mocy testamentu Karola Brzostowskiego, zmarłego 25 lipca 1854 r. w Paryżu, powstała Instytucja Rolno-Fabryczna Sztabińska. Jej pierwszym administratorem został Adolf Gerschoff. Był on inżynierem guberni warszawskiej oraz przyjacielem Karola Brzostowskiego. Siostra testatora Izabela chciała doprowadzić do unieważnienia ostatniej woli zmarłego, jednak jej starania zostały załatwione negatywnie. Od objęcia zarządu Instytucją przez Adolfa Gerschoffa rozpoczął się stopniowy upadek znaczenia tej jednostki organizacyjnej. Adolf Gerschoff prowadził ożywiony spór z okolicznymi włościanami, przerwany przez jego śmierć w 1860 r. Zdefraudował również dużą sumę pieniędzy oraz zdemontował linię telegraficzną, zbudowaną przez hrabiego. Kolejnym administratorem został Henryk Muklanowicz, który w wyniku interwencji Prokuratorii Generalnej Królestwa Polskiego został zdymisjonowany. Jego następcą został Marcin Sztukowski. Sztukowski chciał uratować mienie Instytucji Rolno-Fabrycznej Sztabińskiej, jednak nie udało mu się tego dokonać. W 1883 r. majątek Instytucji został wystawiony na sprzedaż, z wyjątkiem lasu, zwanego Parcelacją Sztabińską. Dobra nabyła księżna Anna Michałowska-Szachowska. W 1909 r. zlicytowano cały majątek Szachowskiej. Parcelacją Sztabińską administrowali mieszkańcy gminy, w szczególności Jakób Rółkowski, proboszcz sztabińskiej parafii w latach 1901-1941. W 1930 r. nadzór nad lasem przejęła Rada Fundacyjna oraz administrator, wyznaczany przez Ministerstwo Spraw Wewnętrznych. Takie rozwiązanie bardzo krytykował ksiądz Rółkowski uważając, że majątek Parcelacji Sztabińskiej jest zbyt mały na utrzymanie administratora. Po II wojnie światowej, w 1948 r. Parcelacja Sztabińska została upaństwowiona.

\section{SUMMARY}

\section{Karol Brzostowski and His Sztabińska Agricultural and Factory Institution}

The Sztabińska Agricultural and Factory Institution was established on the basis of the will of Karol Brzostowski, who died on July 25, 1854 in Paris. Its first administrator was Adolf Gerschoff. Gerschoff was an engineer of Warsaw Governorate and Brzostowski's friend. The testator's sister Izabela wanted to invalidate the deceased's last will, but her efforts had negative results. Since Gerschoff took over the management board of the Institution, the importance of this organizational unit began to decline gradually. Adolf Gerschoff led a lively dispute with the local peasants, interrupted by his death in 1860. He also embezzled a lot of money and disassembled the telegraph line, which Brzostowski built. The next administrator was Henryk Muklanowicz, who was dismissed as a result of the intervention of the General Prosecutor's Office of the Kingdom of Poland. He was succeeded by Marcin Sztukowski. Sztukowski 
wanted to save the property of the Institution. He didn't do it. In 1883, the property of the Institution was put up for sale, with the exception of the forest known as the Sztabin Parcellation. The Institution was acquired by Princess Anna MichałowskaSzachowska. In 1909, the entire Szachowska property was auctioned off. The Sztabin Parcellation was administered by the inhabitants of the commune in particular Jakób Rółkowski, the pastor of Sztabin's parish in the years 1901-1941. In 1930, supervision over the forest was taken over by the Foundation Council and the administrator appointed by the Ministry of the Interior. Jakób Rółkowski strongly criticized this solution. He believed that the property of the Sztabin Parcellation was too poor to pay the administrator. After the Second World War, in 1948 the Sztabińska Parcellation was nationalized. 